\title{
農薬に対する魚類の感受性を比較する方法 ${ }^{1}$
}

\author{
長沢純夫・浅野冒司・近藤和信
}

イハラ農薬研究所

薬物の生物試験を行なうにあたって，供試生物のもつ 大きさの変異の幅が広い場合注，その大きさに応じたな んらかの補正を行ないながら，投与薬量をきめてゆくこ とが必要である。さきに筆者らは，PCP のドジョウに 対する毒性をきめるに際し，体重に基づく size factor を算定して，体重換算薬量と致死時間の関係を一次の回 帰方程式に求めた。このようにして求められた一次の回 帰式をもとに考察すれば，少なくとも大きさの要因だけ は補正されているから, 感受性に関与する諸種の要因の 考察からこれをはずすことが可能である。魚類のよう に，長期同一形態をたもって成長を続けるものにおいて は，大きさの変異の幅が広く，とくに異なった種類の魚 の薬物に対する感受性を比較しょうとする場合などは, 成長の度合もそれぞれに異なるから，両者大きさのそろ ったものを整えて実験を行なうということは，容易でな い。しかしさきに述べたような，解析方法をこれに適用 するならば，そうした不都合は一応解決するはずであ る。本交においては，キンギョとドジョウの殺虫剤 EI43064 に対する感受性を比較した実験結果を例に，その 問題を論ずることとする。

本文にはいるにさきだち，数值の計算にご助力いただ いた高田なつ子嬢に謝意を表する次第である。

\section{実験材料および方法}

供試魚: キンギョ Cyprinus auratus LINNÉ, ドジョ ウ Misgurnus anguillicaudatus (CANTOR) ともに市 販品を用いた。大きさはそれぞれ $2.0 〜 16.0 \mathrm{~g} ， 0.7$ $4.3 \mathrm{~g}$ の範囲にあった。実験に用いる前数日間 $20^{\circ} \mathrm{C}$ 前 後の流水中においた。雌雄の区別は行なわなかった。

供試薬㨈: ここに用いた EI-43064 の code number を有する薬物は 2-(diethoxy phosphinothioylimino)1,3-dithiolaneなる化学名と,<smiles>CCO[P+](=S)N=C(SC)SCC</smiles>

の構造式をもつ American Cyanamid Co. の提供に よる，有機燐殺虫郕の1つである。この $47.0 \%$ 乳剂の 所要量を, 水 $200 \mathrm{cc}$ に乳濁せしめることによって，第 1 表に示すような対数間隔 0.1 にして, 数段階の薬液 を調製した。試験に用いた最高濃度は，キンギョ，ドジ ヨウそれぞれ 1000 および 316 p. p. m. である。

試験方法: 直径 $15 \mathrm{~cm}$, 高さ $18 \mathrm{~cm}$ のガラス製ポッ トに EI-43064 の乳濁液 $200 \mathrm{cc}$ をいれ，これに供試魚 を 1 匹ずつ投入，この投入からわずかの刺戟によっても 反応を示さなくなるまでの時間をはかり，これを致死時 間とした。その後体表面の水分をろ紙で十分吸いとり体 重を測定した。供試薬液は 1 匹ごとにこれを新しくとり かえて用いた。試験中の薬液の温度は $24 \sim 25^{\circ} \mathrm{C}$ であ った。実験は 1962 年 7 月下旬に行なった。

\section{実験結果と考察}

薬量の対数 $x_{1}=\log$ p. p. m., 体重の対数 $x_{2}=\log$ $\mathrm{gm}$, および致死速度（致死時間の逆数）の対数 $y=\log$ (100/分）を個体ごとにまとめた結果が，第 1 表の第

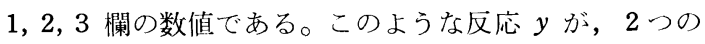
独立変数 $x_{1}, x_{2}$ の函数である関係を, $Y=a+b_{1}\left(x_{1}-\right.$ $\left.\bar{x}_{1}\right)+b_{2}\left(x_{2}-\bar{x}_{2}\right)$ の多重回帰式に表わす方法については, 先報で記した。それにしたがって得られた多重回帰式は つぎのごとくである。

$$
\text { キンギョ } \quad Y=0.05059+0.55765 x_{1}-0.65287 x_{2}
$$

ドジョウ $Y=0.65493+0.43351 x_{1}-0.50521 x_{2}$ これから，個体ごとの体重のちがいを平均化するための “大きさの因子” size factor $b_{2} / b_{1}=h$ を算定すると， それぞれ $-1.17075,-1.16540$ となる。体重換算薬量 $z=x_{1}+h x_{2}$ として，それぞれの $z$ を計算して示したの が 第 1 表第 4 欄の数值である。この $z$ と $y$ との関係 を図示したのが第 1 図で, そこに引かれた回帰線の方程 式はそれぞれ

$$
\begin{array}{lll}
\text { キンギョ } & Y=1.40443+0.51619 & (z-2.42411) \\
\text { ドジョウ } & Y=1.29614+0.43349 & (z-1.45606)
\end{array}
$$

となる。この回帰係数は, さきに求めた $b_{1}$ と rounding

1 魚毒試験に関する研究 第 2 報

(1964 年 1 月 14 日受領) 
第 1 表 EI-43064 乳剂の稀釈溶液に投入後, 降伏までの時間によって测定されたキンギョ打よびトショウの感受性, 稀釈溶液の 濃度の対数 $\left(x_{1}=\log\right.$ p. p. m. $)$ 打よび体重の対数 $\left(x_{2}=\log \mathrm{gm}\right)$ の函数として, 致死速度 $y=\log (100 /$ 分 $)$ を測定。 $z=x_{1}+h x_{2}$ は体重の差によって補正した稀釈楞液の濃度の対数を示す。

\begin{tabular}{|c|c|c|c|c|c|c|c|c|c|c|c|c|}
\hline 魚 & $x_{1}$ & $x_{2}$ & $y$ & $z$ & $x_{1}$ & $x_{2}$ & $y$ & $z$ & $x_{1}$ & $x_{2}$ & $y$ & $z$ \\
\hline & $\begin{array}{l}3.0 \\
3.0 \\
3.0 \\
3.0 \\
3.0\end{array}$ & $\begin{array}{l}0.113 \\
0.146 \\
0.146 \\
0.204 \\
0.204\end{array}$ & $\begin{array}{l}1.613 \\
1.544 \\
1.491 \\
1.580 \\
1.544\end{array}$ & $\begin{array}{l}2.8677 \\
2.8291 \\
2.8291 \\
2.7612 \\
2.7612\end{array}$ & $\begin{array}{l}2.7 \\
2.7 \\
2.7 \\
2.7 \\
2.7\end{array}$ & $\begin{array}{r}-0.097 \\
-0.097 \\
-0.046 \\
0.000 \\
0.146\end{array}$ & $\begin{array}{l}1.634 \\
1.477 \\
1.851 \\
1.456 \\
1.230\end{array}$ & $\begin{array}{l}2.8136 \\
2.8136 \\
2.7589 \\
2.7000 \\
2.5291\end{array}$ & $\begin{array}{l}2.4 \\
2.4 \\
2.4 \\
2.4 \\
2.4\end{array}$ & $\begin{array}{r}-0.046 \\
0.000 \\
0.041 \\
0.176 \\
0.204\end{array}$ & $\begin{array}{l}1.462 \\
1.146 \\
1.415 \\
1.176 \\
1.176\end{array}$ & $\begin{array}{l}2.4539 \\
2.4000 \\
2.3520 \\
2.1940 \\
2.1612\end{array}$ \\
\hline & $\begin{array}{l}3.0 \\
3.0 \\
3.0 \\
3.0 \\
3.0\end{array}$ & $\begin{array}{l}0.255 \\
0.255 \\
0.255 \\
0.278 \\
0.301\end{array}$ & $\begin{array}{l}1.532 \\
1.462 \\
1.568 \\
1.763 \\
1.415\end{array}$ & $\begin{array}{l}2.7015 \\
2.7015 \\
2.7015 \\
2.6745 \\
2.6476\end{array}$ & $\begin{array}{l}2.7 \\
2.7 \\
2.7 \\
2.7 \\
2.7\end{array}$ & $\begin{array}{l}0.204 \\
0.255 \\
0.278 \\
0.301 \\
0.491\end{array}$ & $\begin{array}{l}1.462 \\
1.477 \\
1.491 \\
1.255 \\
1.176\end{array}$ & $\begin{array}{l}2.4612 \\
2.4015 \\
2.3745 \\
2.3476 \\
2.1252\end{array}$ & $\begin{array}{l}2.4 \\
2.4 \\
2.4 \\
2.4 \\
2.4\end{array}$ & $\begin{array}{l}0.230 \\
0.255 \\
0.301 \\
0.380 \\
0.633\end{array}$ & $\begin{array}{l}1.477 \\
1.255 \\
1.362 \\
1.146 \\
1.079\end{array}$ & $\begin{array}{l}2.1307 \\
2.1015 \\
2.0476 \\
1.9551 \\
1.3194\end{array}$ \\
\hline キ & $\begin{array}{l}2.9 \\
2.9 \\
2.9 \\
2.9 \\
2.9\end{array}$ & $\begin{array}{r}-0.079 \\
-0.097 \\
0.000 \\
0.000 \\
0.000\end{array}$ & $\begin{array}{l}1.716 \\
1.653 \\
1.699 \\
1.580 \\
1.544\end{array}$ & $\begin{array}{l}2.9925 \\
3.0136 \\
2.9000 \\
2.9000 \\
2.9000\end{array}$ & $\begin{array}{l}2.6 \\
2.6 \\
2.6 \\
2.6 \\
2.6\end{array}$ & $\begin{array}{r}-0.046 \\
0.000 \\
0.000 \\
0.079 \\
0.204\end{array}$ & $\begin{array}{l}1.398 \\
1.519 \\
1.740 \\
1.544 \\
1.342\end{array}$ & $\begin{array}{l}2.6539 \\
2.6000 \\
2.6000 \\
2.5075 \\
2.3612\end{array}$ & $\begin{array}{l}2.3 \\
2.3 \\
2.3 \\
2.3 \\
2.3\end{array}$ & $\begin{array}{r}-0.097 \\
-0.046 \\
-0.046 \\
0.079 \\
0.146\end{array}$ & $\begin{array}{l}1.544 \\
1.415 \\
1.204 \\
1.279 \\
1.231\end{array}$ & $\begin{array}{l}2.4136 \\
2.3539 \\
2.3539 \\
2.2075 \\
2.1291\end{array}$ \\
\hline ギ & $\begin{array}{l}2.9 \\
2.9 \\
2.9 \\
2.9 \\
2.9\end{array}$ & $\begin{array}{l}0.113 \\
0.146 \\
0.230 \\
0.230 \\
0.255\end{array}$ & $\begin{array}{l}1.634 \\
1.613 \\
1.477 \\
1.602 \\
1.462\end{array}$ & $\begin{array}{l}2.7677 \\
2.7291 \\
2.6307 \\
0.6307 \\
2.6015\end{array}$ & $\begin{array}{l}2.6 \\
2.6 \\
2.6 \\
2.6 \\
2.6\end{array}$ & $\begin{array}{l}0.255 \\
0.278 \\
0.301 \\
0.301 \\
0.301\end{array}$ & $\begin{array}{l}1.204 \\
1.255 \\
1.301 \\
1.255 \\
1.204\end{array}$ & $\begin{array}{l}2.3015 \\
2.2745 \\
2.2476 \\
2.2476 \\
2.2476\end{array}$ & $\begin{array}{l}2.3 \\
2.3 \\
2.3 \\
2.3 \\
2.3\end{array}$ & $\begin{array}{l}0.146 \\
0.176 \\
0.176 \\
0.176 \\
0.204\end{array}$ & $\begin{array}{l}1.342 \\
1.176 \\
1.342 \\
1.176 \\
1.114\end{array}$ & $\begin{array}{l}2.1291 \\
2.0940 \\
2.0940 \\
2.0940 \\
2.0612\end{array}$ \\
\hline & $\begin{array}{l}2.8 \\
2.8 \\
2.8 \\
2.8 \\
2.8\end{array}$ & $\begin{array}{r}-0.097 \\
-0.097 \\
-0.046 \\
0.000 \\
0.000\end{array}$ & $\begin{array}{l}1.544 \\
1.602 \\
1.672 \\
1.568 \\
1.653\end{array}$ & $\begin{array}{l}2.9136 \\
2.9136 \\
2.8589 \\
2.8000 \\
2.8000\end{array}$ & $\begin{array}{l}2.5 \\
2.5 \\
2.5 \\
2.5 \\
2.5\end{array}$ & $\begin{array}{r}-0.097 \\
0.041 \\
0.079 \\
0.146 \\
0.146\end{array}$ & $\begin{array}{l}1.544 \\
1.415 \\
1.477 \\
1.491 \\
1.544\end{array}$ & $\begin{array}{l}2.6136 \\
2.4520 \\
2.4075 \\
2.3291 \\
2.3291\end{array}$ & $\begin{array}{l}2.2 \\
2.2 \\
2.2 \\
2.2 \\
2.2\end{array}$ & $\begin{array}{r}-0.155 \\
-0.046 \\
-0.046 \\
0.146 \\
0.146\end{array}$ & $\begin{array}{l}1.431 \\
1.322 \\
1.146 \\
1.279 \\
1.114\end{array}$ & $\begin{array}{l}2.3815 \\
2.2539 \\
2.2539 \\
2.0291 \\
2.0291\end{array}$ \\
\hline & $\begin{array}{l}2.8 \\
2.8 \\
2.8 \\
2.8 \\
2.8\end{array}$ & $\begin{array}{l}0.113 \\
0.204 \\
0.230 \\
0.278 \\
0.301\end{array}$ & $\begin{array}{l}1.544 \\
1.380 \\
1.580 \\
1.602 \\
1.398\end{array}$ & $\begin{array}{l}2.6677 \\
2.5612 \\
2.5307 \\
2.4745 \\
2.4476\end{array}$ & $\begin{array}{l}2.5 \\
2.5 \\
2.5 \\
2.5 \\
2.5\end{array}$ & $\begin{array}{l}0.255 \\
0.278 \\
0.278 \\
0.342 \\
0.361\end{array}$ & $\begin{array}{l}1.415 \\
1.255 \\
1.602 \\
1.114 \\
1.398\end{array}$ & $\begin{array}{l}2.2015 \\
2.1745 \\
2.1745 \\
2.0996 \\
2.0774\end{array}$ & $\begin{array}{l}2.2 \\
2.2 \\
2.2 \\
2.2 \\
2.2\end{array}$ & $\begin{array}{l}0.176 \\
0.230 \\
0.301 \\
0.301 \\
0.322\end{array}$ & $\begin{array}{l}1.079 \\
1.041 \\
0.778 \\
1.204 \\
0.845\end{array}$ & $\begin{array}{l}1.9940 \\
1.9307 \\
1.8476 \\
1.8476 \\
1.8230\end{array}$ \\
\hline & $\begin{array}{l}2.5 \\
2.5 \\
2.5 \\
2.5 \\
2.5\end{array}$ & $\begin{array}{l}0.301 \\
0.431 \\
0.447 \\
0.477 \\
0.505\end{array}$ & $\begin{array}{l}2.045 \\
1.623 \\
1.591 \\
1.279 \\
1.519\end{array}$ & $\begin{array}{l}2.1492 \\
1.9977 \\
1.9791 \\
1.9441 \\
1.9115\end{array}$ & $\begin{array}{l}2.3 \\
2.3 \\
2.3 \\
2.3 \\
2.3\end{array}$ & $\begin{array}{l}0.477 \\
0.613 \\
0.708 \\
0.732 \\
0.763\end{array}$ & $\begin{array}{l}1.255 \\
1.532 \\
1.255 \\
1.279 \\
1.000\end{array}$ & $\begin{array}{l}1.7441 \\
1.5856 \\
1.4749 \\
1.4469 \\
1.4108\end{array}$ & $\begin{array}{l}2.1 \\
2.0 \\
2.0 \\
2.0 \\
2.0\end{array}$ & $\begin{array}{l}0.964 \\
0.342 \\
0.415 \\
0.477 \\
0.568\end{array}$ & $\begin{array}{l}1.279 \\
1.380 \\
1.301 \\
1.462 \\
1.146\end{array}$ & $\begin{array}{l}0.9766 \\
1.6014 \\
1.5164 \\
1.4441 \\
1.3381\end{array}$ \\
\hline $\begin{array}{l}\text { ド } \\
\text { シ }\end{array}$ & $\begin{array}{l}2.5 \\
2.5 \\
2.5 \\
2.5 \\
2.4\end{array}$ & $\begin{array}{l}0.623 \\
0.681 \\
0.690 \\
1.204 \\
0.477\end{array}$ & $\begin{array}{l}1.342 \\
1.519 \\
1.362 \\
1.176 \\
1.322\end{array}$ & $\begin{array}{l}1.7740 \\
1.7064 \\
1.6959 \\
1.0969 \\
1.8441\end{array}$ & $\begin{array}{l}2.2 \\
2.2 \\
2.2 \\
2.2 \\
2.2\end{array}$ & $\begin{array}{l}0.556 \\
0.591 \\
0.602 \\
0.623 \\
0.708\end{array}$ & $\begin{array}{l}1.398 \\
1.519 \\
1.204 \\
1.114 \\
1.255\end{array}$ & $\begin{array}{l}1.5520 \\
1.5112 \\
1.4984 \\
1.4740 \\
1.3749\end{array}$ & $\begin{array}{l}2.0 \\
2.0 \\
2.0 \\
2.0 \\
1.9\end{array}$ & $\begin{array}{l}0.602 \\
0.756 \\
0.903 \\
0.934 \\
0.477\end{array}$ & $\begin{array}{l}1.204 \\
1.114 \\
1.279 \\
1.041 \\
1.146\end{array}$ & $\begin{array}{l}1.2984 \\
1.1190 \\
0.9476 \\
0.9115 \\
1.3441\end{array}$ \\
\hline ウ & $\begin{array}{l}2.4 \\
2.4 \\
2.4 \\
2.4 \\
2.4\end{array}$ & $\begin{array}{l}0.623 \\
0.623 \\
0.672 \\
0.708 \\
0.724\end{array}$ & $\begin{array}{l}1.398 \\
1.114 \\
1.380 \\
1.279 \\
1.301\end{array}$ & $\begin{array}{l}1.6740 \\
1.6740 \\
1.6169 \\
1.5749 \\
1.5563\end{array}$ & $\begin{array}{l}2.2 \\
2.2 \\
2.2 \\
2.1 \\
2.1\end{array}$ & $\begin{array}{l}0.724 \\
0.740 \\
0.792 \\
0.462 \\
0.544\end{array}$ & $\begin{array}{l}1.255 \\
1.255 \\
1.279 \\
1.362 \\
1.146\end{array}$ & $\begin{array}{l}1.3563 \\
1.3376 \\
1.2770 \\
1.5616 \\
1.4660\end{array}$ & $\begin{array}{l}1.9 \\
1.9 \\
1.9 \\
1.9 \\
1.9\end{array}$ & $\begin{array}{l}0.544 \\
0.568 \\
0.634 \\
0.681 \\
0.681\end{array}$ & $\begin{array}{l}1.230 \\
1.146 \\
1.230 \\
1.000 \\
0.699\end{array}$ & $\begin{array}{l}1.2660 \\
1.2381 \\
1.1611 \\
1.1064 \\
1.1064\end{array}$ \\
\hline & $\begin{array}{l}2.4 \\
2.4 \\
2.3 \\
2.3 \\
2.3\end{array}$ & $\begin{array}{l}0.785 \\
0.935 \\
0.431 \\
0.447 \\
0.462\end{array}$ & $\begin{array}{l}1.398 \\
1.079 \\
1.342 \\
1.532 \\
1.447\end{array}$ & $\begin{array}{l}1.4852 \\
1.3104 \\
1.7977 \\
1.7791 \\
1.7616\end{array}$ & $\begin{array}{l}2.1 \\
2.1 \\
2.1 \\
2.1 \\
2.1\end{array}$ & $\begin{array}{l}0.544 \\
0.580 \\
0.716 \\
0.724 \\
0.756\end{array}$ & $\begin{array}{l}1.146 \\
1.255 \\
1.279 \\
1.231 \\
1.000\end{array}$ & $\begin{array}{l}1.4660 \\
1.4241 \\
1.2656 \\
1.2563 \\
1.2190\end{array}$ & $\begin{array}{l}1.9 \\
1.9 \\
1.9\end{array}$ & $\begin{array}{l}0.708 \\
0.778 \\
0.792\end{array}$ & $\begin{array}{l}1.362 \\
1.279 \\
1.231\end{array}$ & $\begin{array}{l}1.0749 \\
0.9933 \\
0.9770\end{array}$ \\
\hline
\end{tabular}

error しか違っていない。さきに示した $h$ の值から， 体の大きさに基づく感受性の变異を最小にするために は，体重に正比例した薬量を与えるより，体重が大きく なるにしたがって，なお少しずつ少ない薬量を与えるこ とが望ましいといい得る。こうした数値を算定するまで
のう法および得られた数值の説明は，前報にゆずること にして, 計算結果のみを表示すると第 2 表のごとくであ. る。

なお第 1 図に示した両回帰線の傾きは, 若干異なって いるが，かりに平行であるとみなしてその共通勾配を求。 


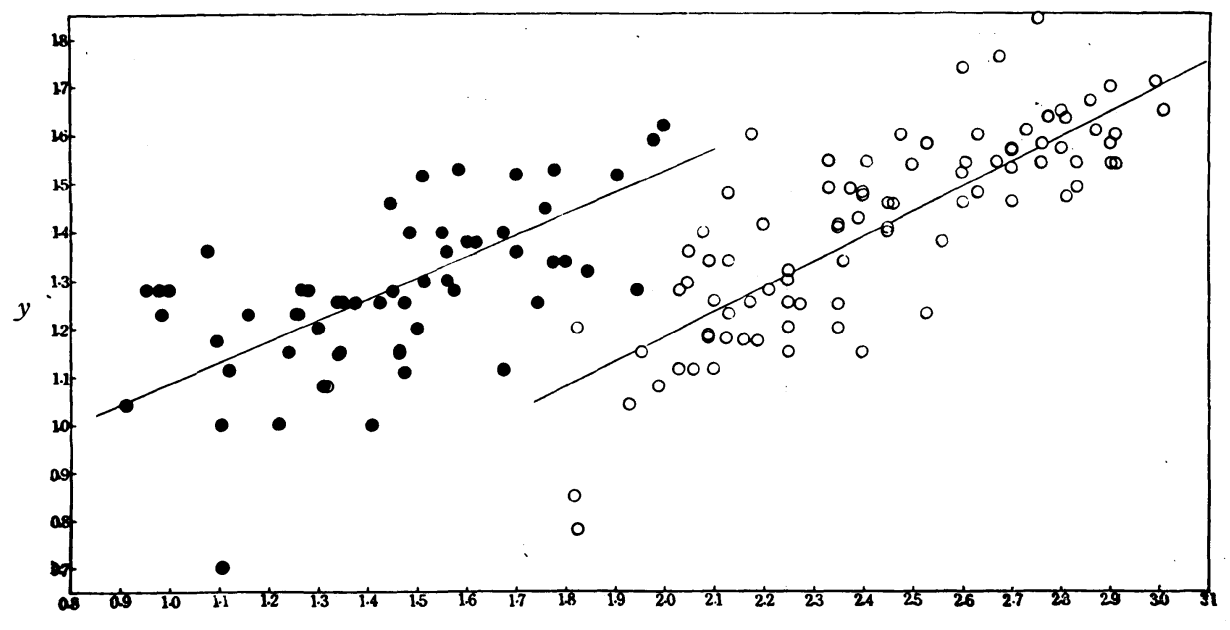

$z$

第 1 図 薬液に投入されてから降伏までの時間によってきめられた致死速度の対数（ $y$ ）と，体 重の差によって補正された EI-43064 の薬量の対数 $(z)$ との関係。白丸：キンギョ， 黒丸：ドジョウ

第 2 表 $2 つ の$ 独立変数をもった回㷌方程式の計算

\begin{tabular}{|c|c|c|c|c|c|}
\hline & キン ギ ヨ & ド シ $\quad \exists$ ウ & & キンギ ヨ & ド ジ ヨウ \\
\hline $\begin{array}{l}N \\
\sum x_{1} \\
\sum x_{2} \\
\Sigma y\end{array}$ & $\begin{array}{l}90 \\
234.0 \\
13.241 \\
126.399\end{array}$ & $\begin{array}{l}58 \\
127.6 \\
37.025 \\
74.596\end{array}$ & $\begin{array}{l}{\left[x_{1} y\right]} \\
{\left[x_{2} y\right]} \\
{\left[y^{2}\right]}\end{array}$ & $\begin{array}{l}3.3407 \\
-1.258710 \\
3.852810\end{array}$ & $\begin{array}{r}1.1031 \\
-0.830866 \\
2.827731\end{array}$ \\
\hline $\begin{array}{l}\bar{x}_{1} \\
\bar{x}_{2} \\
\bar{y}\end{array}$ & $\begin{array}{l}126.399 \\
2.6 \\
0.147122 \\
1.404433\end{array}$ & $\begin{array}{l}7.596 \\
2.2 \\
0.638362 \\
1.286138\end{array}$ & $\begin{array}{l}b_{1} \\
b_{2} \\
a^{\prime} \\
\sum B_{1}^{2}\end{array}$ & $\begin{array}{r}0.557654 \\
-0.652873 \\
0.050586 \\
2.684731\end{array}$ & $\begin{array}{r}0.433509 \\
-0.505210 \\
0.654925 \\
0.897965\end{array}$ \\
\hline $\begin{array}{l}\sum\left(x_{1}^{2}\right) \\
\sum\left(x_{1} x_{2}\right) \\
\Sigma\left(x_{2}^{2}\right) \\
\Sigma\left(x_{1} y\right) \\
\sum\left(x_{2} y\right) \\
\Sigma\left(y_{2}\right)\end{array}$ & $\begin{array}{c}614.40 \\
34.4346 \\
3.882835 \\
331.9781 \\
17.337392 \\
181.371779\end{array}$ & $\begin{array}{c}283.14 \\
81.3481 \\
25.188221 \\
165.2143 \\
46.788391 \\
98.768476\end{array}$ & $\begin{array}{l}R^{2} \\
n \\
s^{2} \\
h \\
C \\
K\end{array}$ & $\begin{array}{c}0.696824 \\
87 \\
0.0134262 \\
-1.17075 \\
1.029268 \\
-0.0000034\end{array}$ & $\begin{array}{c}0.317566 \\
55 \\
0.0350865 \\
-1.16540 \\
1.450993 \\
0.0310466\end{array}$ \\
\hline $\begin{array}{l}{\left[x_{1}{ }^{2}\right]} \\
{\left[x_{1} x_{2}\right]} \\
{\left[x_{2}{ }^{2}\right]} \\
D \\
c_{11} \\
c_{12} \\
c_{22}\end{array}$ & $\begin{array}{c}6.00 \\
0.0080 \\
1.934790 \\
11.608674 \\
0.1666676 \\
-0.0006891 \\
0.5168549\end{array}$ & $\begin{array}{l}2.42 \\
-0.1069 \\
1.552865 \\
3.746505 \\
0.4144830 \\
0.0285332 \\
0.6459343\end{array}$ & $\begin{array}{l}t^{2} \\
\sum z \\
\sum z^{2} \\
\sum z y \\
\bar{z}\end{array}$ & $\begin{array}{c}3.9518 \\
218.1700 \\
538.415427 \\
311.333427 \\
2.424111\end{array}$ & $\begin{array}{r}4.0160 \\
84.4517 \\
127.745266 \\
110.687862 \\
1.456064\end{array}$ \\
\hline
\end{tabular}

め,さきの $y$ と $z$ の関係を計算しなおすと,

キンギョ $\quad Y=0.21999+0.48861 z$

ドジョウ $Y=0.57469+0.48861 z$

となる。これから一定時間にキンギョとドジョウを殺す 薬量の比によって, 両者の EI-43064 に対する感受性 を比較すると,

$$
(0.57469-0.21999) / 0.48861=0.72594
$$

となり, その逆対数値 5.3204 を得る。すなわちドジョ わはキンギョより， 5.32 倍 EI-43064 に対して感受性 であるということができる。
ところで生物の示す感受性の変異法, その大きさだけ をもって説明し得るものでないことはもちろんである。

BLISS の提唱する上記の size factor の概念注，供 試個体群の種類, 令期, 性別などが一定である場合, そ の大きさを補正するために利用することがのぞ志しい。 しかしドジョウのように, 野外で採集されたものは, 老 若が必ずしもその大きさと平行関係にあるものとは思わ れない。また雌雄混合の状態において実験したことも， 大きな変異を生ずる原因であろう。一方異種個体の混入 がなかったともいいきれない。供試魚が薬液に投入され 


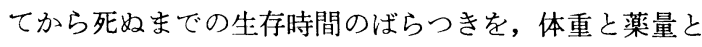
によって説明し得る程度を示第 2 表の $R^{2}$ の值が，キ ンギョの $69.7 \%$ に比べて, ドジョウは $31.8 \%$ にすぎ ない。すなわちドジョウにおいては，ばらつきはこの場 合薬量と体重によって $31.8 \%$ しか説明することができ ず，キンギョよりはるかに体重以外の多くの変異要因を 含えでいたということができる。このように，老若，䧳 雄などを一定にできない場合にも，同様な補正を考えて かなり適合することから，この算定方法はこのような場 合にも適用し得るものとしてよいであろう。それゆえ, 常時一定の大きさをそろえて試験することができない場 合は，こうした解析方法を適用して薬量を補正し，実験 結果を解析することが賢明で，体重によって補正し得る 部分だけでも補正して，その感受性を算定する方法は， ことに異種個体群間の感受性の比較を行なう場合に役立 つであろう。

摘 要

1. 薬物の生物試験を行なうにあたって, 供試生物の もつ大きさの変異の幅が広い場合は，その大きさに応じ たなんらかの補正を行ないながら，投与薬量をきめてい くことが必要である。長期同一形態を保って成長を続け る魚類において，それも野外採集個体を用いるような場 合，また成長度の異なる異種の魚類の感受性を比較する
場合注，とくにそうした考虑が払われなければならな い。

2. 体重に基づく size factor を算定して, 体重換 算薬量と致死時間の関係を方程式に求め, これによって 感受性の程度を考察するならば, 少なくとも大きさに基 ら゙く要因だけは, 考慮の外におくことが可能なはずであ る。

3.この概念をもととして, 浸漬法により, EI-43064 に対するキンギョとドジョウの感受性を比較実験した結 果, 一定時間における致死薬量の比によって示したドジ ョウの EI-43064に対する感受性は, キンギョのそれよ り 5.32 倍高かった。薬液に投入されてから降伏までの 時間のばらつきが, 体重と薬量とによって説明され得る 程度は, ギンギョ $69.7 \%$ に対して, ドジョウは 31.8 \%であった。この場合, ドジョウはキンギョより体重以 外の多くの変異要因をもっていたということができる。

引用文 献

Bliss, C. I. (1936) J. Exptl. Biol. 13: 95 110.

Cyanamid International : Technical Information

(FHT-D103-5C-6304) Experimental Insecticides 43, 064 and $47,031.8 \mathrm{pp}$.

長沢純夫 - 浅野昌司 - 近藤和信 (1963) 応動昆 7: 300 306.

\title{
Summary
}

\section{An Analytical Method for Evaluating the Susceptibility of Fish Species to an Agricultural Chemical ${ }^{2}$}

\author{
By Sumio Nagasawa, Shoji Asano and Kazunobu Kondo \\ Ihara Agricultural Chemicals Institute, Shimizu
}

1. If the variance of size of test organisms used in the biological assay experiment of chemicals is large, the dosage applied must be corrected corresponding to their size. When the field collected fishes are used for test or the susceptibilities between two fish species are compared, the correction of dosage corresponding to their size must be needed as almost all fishes grow in the same shape for long time.
2. "Size factor" for equalizing individual differences in body weight can be calculated by the multiple regression equation that the survival time after immersion was determined as the function of dosage and body weight. If the susceptibilities between two fish species are compared by the regression equation expressed the relation between the survival time after immersion and dosage adjusted for differences in weight,

2 Studies on the Biological Assay of Chemicals to Fishes. II. 
weight factor is expected to eliminate for discussion from the factors affecting the experimental result of fish toxicity test.

3. Based on the general idea mentioned above, the comparative test on susceptibility to EI43, 064 between the goldfish and "Dojo" fish was made by the dipping method. The result has shown that the "Dojo" fish is 5.32 times as susceptible as the goldfish to EI-43,064. As is seen in the figures of $R^{2}$ 's which are the rates explainable the variance in survival time with body weight and dosage are 69.7 and $31.8 \%$ in the goldfish and the "Dojo" fish, respectively. It is considered that the variance of "Dojo" fish was much larger than that of the goldfish from the stand point of biological assay.

\section{殺虫力をもつ新植物成分ニカンドレノン}

O. Nalbandov, R. T. Yамамото and G. S. Fraenkel (1964) Nicandrenone, a new compound with insecticidal properties, isolated from Nicandra physalodes. Jour. Agric. Food Chem. 12 : 55 59 .

タバコスズメガは野外で治ナス科の数種の植物に寄生 するが，実験的に与えれば相当多種類のナス科植物を提 食する。しかしそれらのある種類は，幼虫にたいして 毒性をもち，またある種類たとえばホウズキに近縁な Nicandra physalodes は強い忌避性をもっている。そこ でこの植物の葉から忌避性をもつ物質の抽出を詷みたと こら，水抽出物からク口ロホルムまたはエーテルに移る 劃分が忌避性とともに，スズメガ幼虫にたいして毒性を もち，同時にイエバエにも強い毒作用を示すことがわか った。

つぎにこの作用物質の単離を坛みた。大量の植物体を 風乾粉砕し, 熱水で抽出, 抽出物を順次, 中㘳酢酸鉛, 塩基性酢酸鉛で処理して沈澱物を除いた。得られた水溶 液をアルカリ性でクロロホルムと振盪, クロロホルム風 をとり濃縮して，シリカゲルのクロマトグラフにかけ， さらに精製して仮に Nic 1 と呼ぶ 1 物質を得た。

Nic 1 は約 $1 \mu \mathrm{g}$ の注射で，イエバエ雌成虫にたいし 100\%の致死作用をもつ。またスズメガ幼虫の食物に添 加するると，幼虫はこれを忌避する。無理に損食させると 直ちに麻痖を起し, 死亡率は高い。

この物質は苦味をもち, ワックス状, 融点 $102 \sim 105^{\circ} \mathrm{C}$, 水, 稀酸, 稀アルカリには難溶であるが, 各種有機溶媒 にはよく溶解する。 C , H， Oのみからなり，分子式は $\mathrm{C}_{34} \mathrm{H}_{42} \mathrm{O}_{7}$ である。構造は未確定であるが, 赤外忣収スペ
クトル，紫外部吸収，核磁気共鳴スペクトルなどから， 環状構造をもつケトンであると考えられ，ニカンドレノ ンの名が与无られた。ロテノーンなどと同様にガンマピ ロン誘導体であるらしい。（農技研 平野千里） ショウジョウバエの DNA 連合 RNA

MEAD, C. G. (1964) A Deoxyribonucleic acidassociated ribonucleic acid from Drosophila melanogaster. J. Biol. Chem. 239 : 550 554.

ショウショウバエ幼虫の核酸を遠心分画したところ, 全核酸の $16 \%$ を DNA が，8\% t DNA 連合 RNA がしめているととが判かった。この DNA 連合 RNA は，2本鎖の DNA に RNA が何らかの形で結合して いるもので，最近その存在が微生物に扎いて報告され， その役割が問題となってきていろ。ショウジョヴエの 軽合型核酸结，DNA と RNA が 2 対 1 の割合で結合し て抢り，この RNA の塩基構成出 DNA と相補的な $\mathrm{AU}$ 型（アデニンとウラシル，グアニンとシトシンがそ れぞれ 1 対 1 に含まれる) で，情報伝達系に打いて重 要な働きをしていることがうかがわれる。そこでショウ ショョバエの幼虫を $\mathrm{P}^{32}$-燐酸壳含む培地で飼育し核酸


の大半をしめるリボソーム RNA や可溶性 RNA の分 画にはほとんどとりこまれず，この連合型核酸に急速に とりこまれることが判明した。さらに $\mathrm{P}^{32}$ を含ま奴培 地に幼虫を移与と放射能活性はこの核酸から急速に消失 する。すなわち，乙の連合形核酸はいわゆるメッセンシ ヤ一 RNA の性質とょく一致して抢り，昆虫に找ける 情報伝達系には, DNA の情報を受けた RNA と DNA の結合した形の核酸が重要な役割をしていることが推定 された。

（農技研 藤条純夫） 